\title{
Effects of bacterial infestation caused by human wastes on the skin structures of Mugil platanus Günther, 1880 (Mugilidae)
}

\author{
Langer, SL. ${ }^{\mathrm{a}}$, Vargas, VMF. ${ }^{\mathrm{b}}$, Flores-Lopes, $\mathrm{F}^{\mathrm{d} *}$ and Malabarba, LR. ${ }^{\mathrm{c}}$ \\ ${ }^{\mathrm{a} F a c u l d a d e}$ Cenecista de Osório - FACOS, \\ Rua 24 de maio, 141, CEP 95520-000, Osório, RS, Brazil \\ 'Laboratório de Biologia, Fundação Estadual de Proteção Ambiental Henrique Luiz Roessler - FEPAM, \\ Av. Salvador França, 1707, CEP 90960-000, Porto Alegre, RS, Brazil \\ 'Departamento de Zoologia, Instituto de Biociências - IB, Universidade Federal do Rio Grande do Sul - UFRGS, \\ Av. Bento Gonçalves, 9500, CEP 91501-970, Porto Alegre, RS, Brazil \\ dDepartamento de Ciências Biológicas, Universidade Estadual de Santa Cruz - UESC, \\ Rod. Ilhéus-Itabuna, Km 16, CEP 45650-000, Ilhéus, BA, Brazil \\ *email: fabiologo5@hotmail.com \\ Received February 28, 2007 - Accepted July 3, 2007 - Distributed May 31, 2009
}

(With 2 figures)

\begin{abstract}
Manifestation of infectious pathologies in fishes usually increases in environments where organic wastes are disposed. Specimens of Mugil platanus Günther, 1880 and water samples collected at three points of the Tramandaí river were analyzed during a one year period. The macroscopic observation revealed ulcerations in the caudal peduncle area covered with a mass of amorphous and whitened tissues. Histopathologic analysis showed the presence of negative gram bacteria, probably responsible for alterations of the normal structure of the epidermic tissues. Non-parametric statistical analysis for ammonia concentration showed a significant variation among the three collected spots as well as in the multiple comparison between two spots. In this study, we describe cutaneous lesions observed in Mugil platanus specimens and tested their correlation with environmental ammonia concentration.
\end{abstract}

Keywords: Mugil platanus, histopathology, ammonia.

\author{
Efeitos da infestação de bactérias provocada por resíduos \\ humanos na pele de Mugil platanus Günther, 1880 (Mugilidae)
}

\section{Resumo}

A manifestação de patologias infecciosas em populações de peixes costuma ser incrementada em ambientes onde são lançados despejos orgânicos. Exemplares da espécie Mugil platanus Günther, 1880 coletados em três pontos do rio Tramandaí foram utilizados para análise das alterações, e amostras de água foram tomadas durante o período de um ano para verificação da presença de bactérias. A observação macroscópica revelou ulcerações na região do pedúnculo caudal revestidas por uma massa de tecido amorfo e esbranquiçado. A análise histopatológica mostrou a presença de bactérias gram negativas, que provavelmente foram as responsáveis pela alteração da estrutura normal dos tecidos de revestimento do corpo. O resultado da análise estatística não paramétrica para a concentração de amônia mostrou variação significativa entre os três pontos amostrados bem como nas comparações múltiplas entre os pontos dois a dois. Este trabalho descreve as lesões cutâneas observadas em Mugil platanus e testa sua correlação com a concentração de amônia.

Palavras-chave: Mugil platanus, histopatologia, amônia.

\section{Introduction}

Functional disturbances in fish, besides affecting their biological characteristics and increasing vulnerability to unfavourable environmental factors, also harm the fish defense mechanism, giving way to the action of secondary factors such as disease caused by parasites or

infectious agents (Mitrovic, 1970). It is known that the manifestation of infectious pathologies in fish populations usually happens in environments where organic wastes are disposed, which determine a high proliferation of vibrions and pathogenic bacteria (Mason, 1991; 
Robbins et al., 1996; du Vivier, 1997). Bacteria are organisms that can be very critical in fish cultures due to the diseases they can cause, which frequently have a noticeable economic impact on fish populations. Mortality rates are sometimes very high, especially in cases where infection causes stress for the host (Bruno, 1992).

Mason (1991) and du Vivier (1997) have reported that bacteria surface proteins (involved in the adherence of the cells), enzymes (which break up the proteins), and exotoxins (which degenerate host cells, causing the scalded-skin syndrome) are some of the factors that cause their effects. Bacteria cause pyogenic inflammation - when they stay inside the skin, lungs, bones or heart valves - known for its capacity for local destruction (Robbins et al., 1996). Noga (2000) reviewed the multitude of factors and agents associated with skin ulceration in fish. He concluded that skin ulceration is a wellrecognized indicator of a polluted or otherwise stressed aquatic environment which involves a complex array of biological and physical risk factors and host responses. Lang et al. (1999) discussed the possible etiologies that included fishing gear trauma, pollution and salinity gradients and poor body condition. They concluded that etiology was obscure in most cases, in spite of a greater prevalence in more degraded habitats. It was difficult to relate ulcers to specific chemicals or pollutants.

The synergy of certain substances such as ammonia, nitrate, nitrite, sulfur and others present in the environment, can intensify the toxic effect of these substances and can be a growth factor for certain populations of bacteria (Robbins et al., 1996). According to Svobodova and Kolarova (2004), under normal circumstances, ammonia in the aquatic environment is oxidized to nitrites and these are oxidized to nitrates. For those authors, nitrates, as opposed to nitrites, are slightly toxic for fish and the incomplete oxidation of ammonia may happen in recirculating systems of fish culture. Nitrites penetrate through the gills to the blood, bind to haemoglobin and form methaemoglobin. This decreases the oxygen transporting capacity of the blood and structural changes of hepatic cells also occur (Svobodova and Kolarova, 2004).

The exact mechanisms of ammonia toxicity, considered as a major neurotoxin in mammals, remain unclear in teleosts (Mommsen and Walsh, 1992). High ammonia concentrations are a limiting factor in farm fishing because such concentrations cause a growth rate decrease, plasma cortisol increase, gill damage, impairment of gas diffusion, and excessive mucus production (Wright, 1995). Sensitivity of many freshwater teleosts to increasing external ammonia concentrations can culminate in death (Dabrowska and Wlasow, 1986).

This paper describes the cutaneous lesions observed in Mugil platanus Günther, 1880 specimens probably caused by the action of bacteria, relating the occurrence of these lesions to the variation of the environmental ammonia concentration.

\section{Material and Methods}

Samples of Mugil platanus were obtained at three spots on the Tramandaí river: spot 1 is located in the city of Tramandaí, $20 \mathrm{~m}$ from the Tramandaí-Imbé bridge (the limit between the two cities), defined as an area of disposal of fishing leftovers; spot 2 is located in the city of Imbé, $15 \mathrm{~m}$ from the same bridge, at the left shore, defined as an area of disposal of domestic waste; spot 3 is also located in the city of Imbé, but $6 \mathrm{~km}$ upstream from the bridge, at the shore opposite to the joining of the river with the Imbé lagoon channel, with a minimum distance of $600 \mathrm{~m}$ from the shore. Spot 3 was considered a spot of reference with less environmental interference.

Water samples were taken monthly to analyze the $\mathrm{pH}$ and the ammonia concentration (a total of 10) from January to November 2002. No fieldwork was done in July due to improper weather conditions. Samples were analyzed in the field, using kits of LabconTest - pH Tropical and LabconTest - Ammonia/ $\mathrm{NH}_{3} / \mathrm{NH}_{4}$. One water sample from spot 2 was taken to the Laboratory of Clinic and Toxic Analysis - TOXILAB, to analyse the presence of bacteria and to quantify them. Simultaneously, a second sample (taken from the same spot) was taken to the Químioambiental laboratory to obtain the specific typology of the bacteria, applying various methods such as the multiple-tube method, Fluorescence, Pour Plate, Spread Plate and classic Biochemistry.

Forty to fifty young Mugil platanus specimens were randomly sampled in each of the four sampling periods (Jan-Feb; Mar-Apr; May-Jun and Oct-Nov), using a seine net $(0.5 \mathrm{~cm}$ mesh size). The specimens were immediately fixed in formalin $10 \%$ and were later examined for the registration of external anomalies. During the analysed period, the number of fishes obtained in each spot was considered, defining the healthy and the anomalous ones (Table 1). The standard length and weight were measured.

Pieces of the body lateral portion of the specimens obtained during Oct-Nov sampling were decalcified with trichloroacetic acid 5\%, for a period of 12 hours, dehydrated with ethanol, embedded in paraffin, and sectioned at 6-7 $\mu \mathrm{m}$. A routine histological technique of Hematoxylin-eosin (HandE) was used for the visualization of the tissues and the Gram Method (Michalany, 1980) was used to verify the presence and to identify the bacteria.

The differences in $\mathrm{pH}$ and ammonia concentration among different sampling spots were evaluated by the non-parametric analysis of variation of Kruskal-Wallis for multiple comparisons.

\section{Results}

During the study period, 176 young individuals of Mugil platanus were captured, and the standard length varied from $12.5 \mathrm{~mm}$ to $45 \mathrm{~mm}$ and the weight varied from 0.528 to $1.654 \mathrm{~g}$. The skin of the young individuals of Mugil platanus is constituted by a small number 
of layers of epithelial tissue (usually from two to five). Between these are the scales, which are imbricate. Some loose conjunctive tissue and smooth muscle tissue can be seen with the scales. Below the scales there is a layer of dense conjunctive tissue and right below it, a thick layer of melanin and chromatophores. The skeletal striated muscle was found below this pigment layer (Figure 1a).

The macroscopic analysis of the altered individuals of Mugil platanus revealed ulcerations in the area of the caudal peduncle, covered by a mass of amorphous tissue, which presented a whitened coloration (Figures 1b, 1c, 1d). The histopathologic analysis of these ulcerations allowed us to verify the presence of gram-negative bacteria, which were probably responsible for the major changes in the normal structure of the tissues. The observed bacteria presented a round shape and were grouped in various colonies spread among the entire affected area (Figures 1b to 1d). The epithe-

Table 1. Number of specimens of Mugil platanus examined by locality and by month of collection, and the absolute frequency of anomalous specimens per spot.

\begin{tabular}{lrcccccc}
\hline \multicolumn{1}{c}{ Period } & \multicolumn{2}{c}{ Spot 1 } & \multicolumn{2}{c}{ Spot 2 } & \multicolumn{3}{c}{ Spot 3 } \\
\cline { 2 - 8 } & N & Anomalous & N & Anomalous & N & Anomalous & Total \\
\hline Jan.-Feb. & 50 & 2 & 50 & 4 & 50 & 0 & 150 \\
Mar.-Apr. & 50 & 2 & 50 & 5 & 50 & 0 & 150 \\
May-June & 40 & 1 & 40 & 3 & 40 & 0 & 120 \\
Oct.-Nov. & 36 & 2 & 36 & 6 & 36 & 0 & 108 \\
Total & 176 & 7 & 176 & 18 & 176 & 0 & 528 \\
\% anomalous & - & 4 & - & 10 & - & 0 & 05 \\
\hline
\end{tabular}
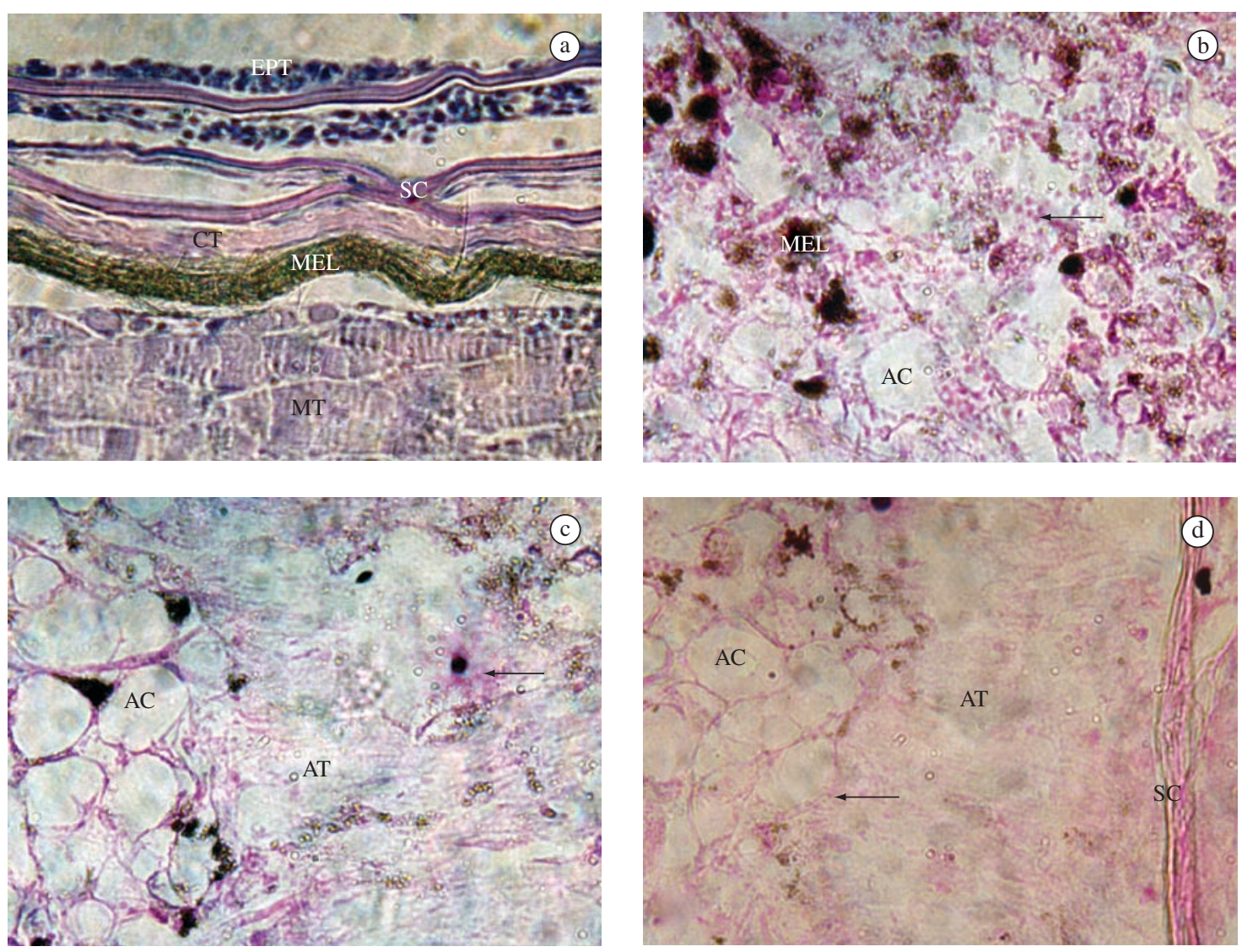

Figure 1. Histology and histopathology of the skin of Mugil platanus. a) normal skin, H\&E (400x); b) Ulceration of the skin with loss of the normal structure and showing colonies of bacteria, adipose cells and amorphous tissue, Gram Method (400x); c) colonies of bacteria, adipose cells and amorphous tissue, Gram Method (400x); d) Amorphous tissue between colonies of bacteria, fatty cells and traces of scales, Gram Method (400x). EPT -Epithelial tissue; SC - Scales; MEL - Melamin; CT - Conjunctive tissue; MT - Muscular tissue; AC - Adipose Cells; AT - Amorphous Tissue; Arrow- Colonies of Bacteria. 
lial tissue practically disappeared, so we could only find amorphous tissue and adipose cells (Figures 1c e 1d). The scales, smooth muscles, and conjunctive tissue are practically absent, since they are greatly altered.

The fibres of striated muscle also had their spindle and extended shape greatly altered. The laboratory analysis of the water sample taken from spot 2 confirmed the presence of heterotrophic bacteria in quantities above the acceptable level. Using "in vitro" culture, the presence of Staphylococcus aureous in the water was detected. The methods of multiple tubes, Fluorescence, Pour Plate, Spread Plate and classic Biochemistry also detected the presence of Enterococcus faecalis, Escherichia coli, Pseudomonas aeruginosa and aerobic mesophile microorganisms.

Spot 2, as shown in Table 1, presented the highest number of fishes with tissue alterations: 6 during Oct-Nov, 5 during Mar-Apr, 4 during Jan-Feb and 3 during May-Jun. In spot 1, however, the occurrence was more constant: 2 during Oct-Nov, Mar-Apr and Jan-Feb, and 1 during May-Jun. In spot 3, no alterations were observed during the 4 sampling periods. The analysis of water samples for 10 months, from January to November, detected ammonia in spots 1 and 2, presenting, respectively, $0.25 \mathrm{ppm}$ (minimum value) and $0.28 \mathrm{ppm}$ (maximum value); $0.28 \mathrm{ppm}$ (minimum value) and $0.83 \mathrm{ppm}$ (maximum value). In spot 3 , considered as a reference point, the presence of ammonia was not detected (Table 2).

$\mathrm{pH}$ values for spots 1 and 2 presented a variation according to the differences in environmental conditions, varying from 7.1 to 7.6 for spot 1 and from 7.3 to 7.8 for spot 2. The $\mathrm{pH}$ value for spot 3 was 7.0 during the whole studied period (Table 2). During sampling periods, the environmental temperature varied from $14{ }^{\circ} \mathrm{C}$ in June (minimum) to $28{ }^{\circ} \mathrm{C}$ in January and February (maximum) (Table 2).

The evaluation of the $\mathrm{pH}$ values between these three spots indicates significant values $(p=0.0001)$, as well as with the multiple non-parametric comparisons between spots 1 and $3(\mathrm{p}=0.0096)$, and spots 2 and $3(\mathrm{p}=0.0001)$. For spots 1 and 2, no significant differences were observed $(p=0.1518)$. Therefore, spots 1 and 2 presented values significantly superior than those at spot 3 .

There was a significant variation in ammonia concentration among the three sampled spots ( $p=0.0001)$, as well as in the multiple non-parametric comparison between two spots, causing significant differences between spot 1 and spot $3(\mathrm{p}=0.01)$, spots 2 and $3(\mathrm{p}=0.01)$ and spots 1 and 2 $(p=0.03)$. Therefore, the results show a significant gradient in ammonia concentration presenting different values from one spot to another. The highest ammonia concentration was observed in spot 2 , followed by spot 1 .

\section{Discussion}

There is a vast literature about fish diseases caused by various environmental stress factors, among which are etiologic agents (Snieszko, 1974), but there is little information on the effect of these stress agents on the incidence of infectious fish diseases. The same author believes that disease is the final result of an interaction between noxious stimuli and a biotic system, and that in order to understand a disease, it is necessary to understand all the biologic aspects of the species. Walters and Plumb (1980) observed that the environment is the most important and unstable of the three factors that influence the appearance of a disease, and its importance is intensified by the presence of potential pathogenic agents that normally exist in water. Wedemeyer and Wood (1974) observed that the aquatic environment presents many independent and interdependent balanced variables, which can easily, and sometimes quickly, be changed. Chemical changes in water can be directly lethal to fishes and sublethal changes might stress the fish to a point that it becomes more vulnerable to infectious diseases. Snieszko (1974) observed that, in order to discuss the role of environmental stress agents in the development of infectious

Table 2. $\mathrm{pH}$ and ammonia values by locality and by month of collection; $\left[\mathrm{NH}_{3}\right]$ Concentration of ammonia in ppm; Temperature in ${ }^{\circ} \mathrm{C}$.

\begin{tabular}{|c|c|c|c|c|c|c|c|c|c|}
\hline \multirow[t]{2}{*}{ Period } & \multicolumn{3}{|c|}{ Spot 1} & \multicolumn{3}{|c|}{ Spot 2} & \multicolumn{3}{|c|}{ Spot 3} \\
\hline & pH & {$\left[\mathrm{NH}_{3}\right]$} & $\mathbf{T}$ & pH & {$\left[\mathrm{NH}_{3}\right]$} & $\mathbf{T}$ & pH & {$\left[\mathrm{NH}_{3}\right]$} & $\mathbf{T}$ \\
\hline Jan. & 7.5 & 0.28 & 28.0 & 7.7 & 0.75 & 28.0 & 7.0 & 0.0 & 28.0 \\
\hline Feb. & 7.5 & 0.28 & 28.0 & 7.5 & 0.75 & 28.0 & 7.0 & 0.0 & 28.0 \\
\hline Mar. & 7.6 & 0.25 & 24.0 & 7.7 & 0.28 & 24.0 & 7.0 & 0.0 & 24.0 \\
\hline Apr. & 7.2 & 0.27 & 20.0 & 7.5 & 0.30 & 20.0 & 7.0 & 0.0 & 20.0 \\
\hline May & 7.1 & 0.27 & 18.0 & 7.5 & 0.30 & 18.0 & 7.0 & 0.0 & 18.0 \\
\hline June & 7.5 & 0.28 & 14.0 & 7.7 & 0.30 & 14.0 & 7.0 & 0.0 & 14.0 \\
\hline Aug. & 7.2 & 0.25 & 16.0 & 7.3 & 0.75 & 16.0 & 7.0 & 0.0 & 16.0 \\
\hline Sept. & 7.2 & 0.27 & 25.0 & 7.7 & 0.75 & 25.0 & 7.0 & 0.0 & 25.0 \\
\hline Oct. & 7.3 & 0.25 & 24.0 & 7.5 & 0.77 & 24.0 & 7.0 & 0.0 & 24.0 \\
\hline Nov. & 7.5 & 0.25 & 24.0 & 7.8 & 0.83 & 24.0 & 7.0 & 0.0 & 24.0 \\
\hline
\end{tabular}


diseases in fishes (especially those of bacterian etiology), the relation between the noxious stimuli and the development of the disease must be considered.

In this study, a greater frequency of Mugil platanus specimens affected probably by the action of bacteria was observed in spots 1 and 2. Spot 2 had the highest frequency. The results of the study also showed a significant relation between the frequency of individuals of Mugil platanus with tissue alterations in the skin and the variation in ammonia concentration in the environment, indicating that ammonia can be the most probable cause for cutaneous alterations in Mugil platanus. Therefore, the high frequency of tissue alteration must be related to the fact that spot 2 receives a greater amount of domestic waste that causes higher ammonia concentration mostly in the summer months when the human population presence increases (Table 2 and Figure 2). This suggests that ammonia works as a support for these pathogenic organisms, drawing the conclusion that there is a negative impact of the anthropic influence on the environment of the estuary and on the fish population, caused by fishing leftovers and disposal of domestic waste.

High $\mathrm{pH}$ values and ammonia concentration for spots 1 and 2 can cause an increase in the toxicity of the ammonia, harmful to the local fish population (Smart, 1978; Moreira and Marcon, 1998). The statistical analysis showed a statistically significant result for the relation between the variation of $\mathrm{pH}$ and the frequency of anomaly occurrences in spots 1 and 2 . No statistically significant results were obtained for spot 3. Niesink et al. (1996) have observed that increasing the temperature also increases the toxicity of the ammonia, proving that it is a variable of synergic effect, which we have not observed in this study (Table 2). High ammonia concentration (Table 2) can be one of the factors that allow bacteria proliferation (Staphylococcus aureus and Pseudomonas aeruginosa included), since it is a growth factor for these bacterial populations.

There are bacteria that are generically designated as secondary pathogenic organisms, or secondary invasive, that only manifest their pathogenic capacity when conditioned by a debilitated state of the host (Heo et al., 1990). On the other hand, there are bacteria that are primary

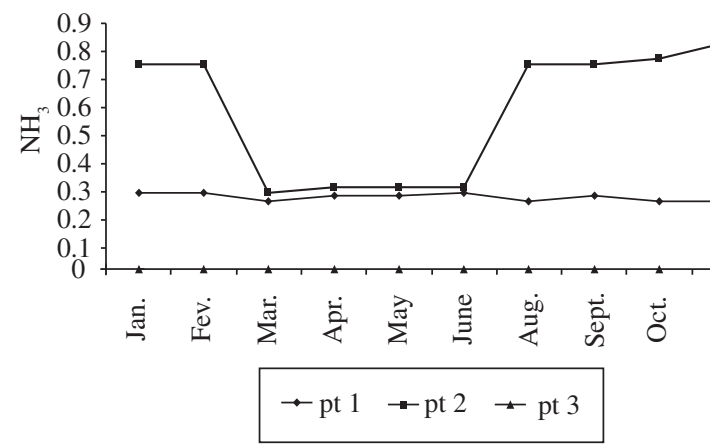

Figure 2. Variation of ammonia concentration in the Tramandaí river during the studied period. pathogenic agents, or primary invasive, which can, on their own, start an infection if the host is subject to minor stress (Bruno, 1986). The bacteria might be associated to various pathogenic phenomena, which are usually divided into three main aspects: septicemic response, tegument and muscle necrosis causing ulceration, and proliferation chronic response (Pavanelli et al., 1998).

The results of our study indicate that secondary pathogenic bacteria characteristic of anthropic influence, especially Staphylococcus aureus and Pseudomonas aeruginosa which were observed in the water samples, are the most probable cause of tissue lesions observed in Mugil platanus specimens. The tissue lesions detected were tegument and caudal peduncle muscles necrosis and they were different in each of the sampling spots. Ours results are similar to the ones described by Rehulka (2002), which verified enormous prominent bulges developed on fish skin and the lesions were filled with clear to slightly turbid exudate, in some cases with a slight tint of blood. On a cut section, they exposed haemorrhagically altered muscle. This tissue does not disintegrate under the skin bulge and does not produce crater-like furuncles because the pathological process did not reach deeper layers.

Snieszko (1974) mentioned that, among the numerous pathogenic agents of fishes, bacteria from genera Pseudomonas and Aeromonas are worth mentioning. According to the literature, bacteria of fecal origin, as a result of the disposal of domestic effluents with no previous treatment, can proliferate in the environment and cause cutaneous lesions in fish. It is known that the manifestation of infectious pathologies in fish populations is usually incremented in environments where organic wastes are thrown, which determine a high proliferation of vibrios and pathogenic bacteria (Mason, 1991; Robbins et al., 1996; du Vivier, 1997).

The physiological phenomena that happen to fishes and favor bacteria invasion and proliferation are not entirely known, but they are certainly related to a decrease in the capacity of the host's immune system (Pavanelli et al., 1998). The sub-lethal effects of chemical contaminants thrown into the environment are, according to Leikin and Paloucek (1998), extremely harmful, slowly affecting (usually unnoticed) functions that assure the renewal of fish populations, such as sexual maturing and eggs and larvae survival.

The Mugil platanus population characteristically occupies regions of salt-water influence of the estuary for feeding and growing, where they are usually captured by fishing activity. Since diseases caused by bacteria originated from human activity are affecting the juveniles of this species, this can compromise the maintenance of fish stocks in the estuary.

Flores-Lopes et al. (2001; 2002) used the presence of lesions/anomalies in fish species as an instrument of biological evaluation of environmental quality. The results obtained in our study with Mugil platanus specimens, re- 
assure the importance of using anomalies as indicators of environmental alterations and degradations of anthropic origin which compromise the quality of ecosystems.

Acknowledgements - We are grateful to Felipe Antunes and Bernardo Duarte, FACOS-FACAD-MARQUÊS-CNEC/Osório$\mathrm{RS}$, for their help in the fieldwork.

\section{References}

BRUNO, DW., 1986. Furunculosis in sea-reared Atlantic salmon, Salmo salar L: colonization of the gill epithelium. Bulletin of the European Association of Fish Pathologists, vol. 6, no. 3, p. 76-79.

1992. Cytophaga psychrophila $(=$ Flexibacter psychrophilus) (Borg.) histopathology associated with mortalities among farmed rainbow trout, Oncorhynchus mykiss (Walbaum) in the U.K. Bulletin of the European Association of Fish Pathologists, vol. 12, no. 6, p. 215-216.

DABROWSKA, H. and WLASOW, T., 1986. Sublethal effect of ammonia on certain biochemical and hematological indicators in common carp. Comparative Biochemistry and Physiology, vol. 83 C, no. 1 , p. $179-184$

Du VIVIER, A., 1997. Atlas de dermatologia clínica. 2 ed. São Paulo: Editora Manole Ltda. 586p.

FLORES-LOPES, F., MALABARBA, LR., SILVA, JF. and PEREIRA, EHL., 2001. Alterações histológicas em placas ósseas do peixe cascudo Rineloricaria strigilata (Hensel) (Teleostei, loricariidae) e sua frequiência no lago Guaíba, Rio Grande do Sul, Brasil. Revista brasileira de Zoologia, vol. 18, no. 3, p. 699-709.

FLORES-LOPES, F., MALABARBA, LR., SILVA, JF. and PEREIRA, EHL., 2002. Histologia de deformidades vertebrais em Astyanax alburnus (HENSEL, 1870) (OSTARIOPHYSI: CHARACIDAE) do Lago Guaíba, Rio Grande do Sul, Brasil. Comunicações do Museu de Ciências e Tecnologia da PUCRS, Série Zoologia, vol. 15, no. 1, p. $137-155$.

HEO, GH., KASAI, K. and WAKABAYASHI, H., 1990. Occurrence of Flavobacterium branchiophila associated with bacterial gill disease at a trout hatchery. Fish Pathology, vol. 25, no. 2, p. 99-105.

LANG, T., MELLERGAARD, S., WOSNIOK, W., KADAKAS, V. and NEUMANN, K., 1999. Spatial distribution of grossly visible diseases and parasites in flounder (Platichthys flesus) from the Baltic Sea: a synoptic survey. ICES Journal of Marine Science, vol. 56, p. 138-147.

LEIKIN, JB. and PALOUCEK, FP., 1998. Poisoning and toxicology compendium. Cleveland: Lexi-Comp Inc.1465p.

MASON, CF., 1991. Biology of freshwater pollution. 2 ed. London: Longman Scientific \& Technical. 351p.
MICHALANY, J., 1980. Técnica histológica em anatomia patológica, com instruções para o cirurgião, enfermeira $e$ citotécnico. São Paulo: EPU. 277p.

MITROVIC, VV., 1970. Sublethal effects of pollutants on fish. In RUIVO, M. (Ed.). Marine pollution and sea life. London: Fishing News (Books) Ltd. 374p.

MOMMSEN, TP. and WALSH, PJ., 1992. Biochemical and environmental perspectives onnitrogen metabolism in fishes. Celular and Molecular Life Sciences, vol. 48, no. 6, p. 583-593.

MOREIRA, SS. and MARCON, JL., 1998. Toxicidade da amônia em peixes da Amazônia: determinação da concentração média letal (CL50) em Colossoma macropomum cultivado na região de Manaus. Manaus: [s.n.]. 22p. Relatório Final PIBIC (CNPq/UA).

NIESINK, RJM., VRIES, J. and HOLLINGER, MA., 1996. Toxicology: principles and applications. New York: CRC Press; Boca Raton. 1284p.

NOGA, E., 2000. Skin ulcers in fish: pfiesteria and other etiologies. Toxicol Pathol, vol. 28, p. 807-823.

PAVANELLI, GC., EIRAS, JC. and TAKEMOTO, RM., 1998. Doenças de peixes: profilaxia, diagnóstico e tratamento. Maringá: EDUEM; CNPq. 264p.

REHULKA, J., 2002. Aeromonas causes severe skin lesions in Rainbow Trout (Oncorhynchus mykiss): clinical pathology,haematology and biochemistry. Acta Veterinaria Brno, vol. 71, p. 351-360.

ROBBINS, SL., COTRAN, RS. and KUMAR, V., 1996. Fundamentos de patologia estrutural e funcional. 5 ed. Rio de Janeiro: Editora Guanabara Koogan. 605p.

SMART, GR., 1978. Investigations of the toxic mechanisms of ammonia to fish: gas exchange in rainbow trout (Salmo gairdneri) exposed to acutely lethal concentrations. Journal of Fish. Biology,vol. 12, no. 1, p. 93-104.

SNIESZKO, SF., 1974. The effects of environmental stress on outbreaks of infectious diseases of fishes. Journal of Fish Biology, vol. 6, no. 2, p. 197-208.

SVOBODOVA, Z. and KOLAROVA, J., 2004. A review of the diseases and contaminant related mortalities of tench (Tinca tinca L.). Veterinary Medicine, vol. 49, no. 1, p. 19-34.

WALTERS, GR. and PLUMB, JA., 1980. Environmental stress and bacterial infection in channel catfish, Ictalurus punctatus Rafinesque. Journal of Fish Biology, vol. 17, no. 2, p. 177-185.

WEDEMEYER, G. and WOOD, JW., 1974. Stress as a factor in fish diseases. [S.L.]: [s.n.]. 8p. U.S. Fish Wildl. Serv. Fish Dis. Leafl.

WRIGHT, PA., 1995. Review: nitrogen excretion: three end products, many physiological roles. Journal of Experimental Biology, vol. 198, no. 2, p. 273-281. 